\title{
INTELIGÊNCIA, RAZÃO DE ESTADO E A ARTE DE GOVERNAR \\ RISCO E OPORTUNIDADE NO INÍCIO DO ESTADO EUROPEU MODERNO ${ }^{1}$
}

\author{
INTELLIGENCE, REASON OF STATE AND THE ART OF \\ GOVERNING
} RISK AND OPPORTUNITY IN EARLY MODERN EUROPE

Steven Hutchinson ${ }^{2}$ Universidade de Leeds - UK

\begin{abstract}
Resumo
Baseando-se em material histórico primário e secundário, este artigo explora o papel da inteligência no início do governo moderno. Foca-se nos desenvolvimentos da Inglaterra no século XVII e início do século XVIII, em um momento genealógico específico do local na história mais ampla do poder e conhecimento do Estado. Seguindo a tendência do trabalho foucaultiano em negligenciar a governança pré-século XVIII, a análise revela um conjunto de processos interrelacionados que deram origem a uma inovação técnica para prever riscos e oportunidades para o Estado. No cruzamento da raison d'Etat, a arte de governar em evolução, rotinas de sigilo generalizadas e uma pós-Westfália no domínio da concorrência e do intercâmbio europeus, a inteligência foi concebida como uma solução fundamental aos problemas simultâneos de assegurar a paz e a estabilidade, ao mesmo tempo que melhoram as forças estatais. Nos escritórios administrativos da Secretaria de Estado inglesa, uma assembleia de procedimentos interrelacionados buscava produzir e manipular informações de maneira que fossem expostos ambos os riscos possíveis para o Estado e para as potenciais oportunidades de expansão e ganho. Como isso sugere, a arte da inteligência desempenhou um papel importante, ainda que não reconhecido, na formação e crescimento no início do Estado moderno. Garantindo vantagem estratégica sobre os rivais, a inteligência também limitou a capacidade dos
\end{abstract}

1 Tradução de Caroline Bussoloto. Revisão de Ricardo Jacobsen Gloeckner.

2 Steven Hutchinson é Pesquisador Associado em Criminologia e Justiça Criminal na Universidade de Leeds, no Reino Unido. Ele leciona nos programas de pós-graduação da Faculdade de Direito, e sua pesquisa atual explora as interseções entre inteligência, segurança e governo. 


\title{
DELICTAE, Vol. 4, Nº, Jan..-Jun. 2019 109
}

vizinhos da Inglaterra de dominar o comércio, controlar os mares, dominar as colônias, funcionando como uma característica constitutiva de balanço e equilíbrio europeus. Conforme a análise conclui, entender a inteligência como uma forma de técnica - uma maneira de fazer algo - revela uma forma inteiramente nova de pensar e investigar suas inúmeras formações (históricas e contemporâneas).

Palavras-chaves

Inteligência. Segurança. Governo. Razão de Estado. Soberania.

\begin{abstract}
Drawing upon primary and secondary historical material, this paper explores the role of intelligence in early modern government. It focuses upon developments in seventeenth- and early-eighteenth-century England, a site-specific genealogical moment in the broader history of state power/ knowledges. Addressing a tendency in Foucauldian work to neglect pre-eighteenth-century governance, the analysis reveals a set of interrelated processes which gave rise to an innovative technique for anticipating hazard and opportunity for the state. At the intersection of raison d'Etat, the evolving art of government, widespread routines of secrecy and a post-Westphalia field of European competition and exchange, intelligence was imagined as a fundamental solution to the concurrent problems of ensuring peace and stability while improving state forces. In the administrative offices of the English Secretary of State, an assemblage of complex and interrelated procedures sought to produce and manipulate information in ways which exposed both possible risks to the state and potential opportunities for expansion and gain. As this suggests, the art of intelligence played an important if largely unacknowledged role in the formation and growth of the early modern state. Ensuring strategic advantage over rivals, intelligence also limited the ability of England's neighbours to dominate trade, control the seas and master the colonies, functioning as a constitutive feature of European balance and equilibrium. As the analysis concludes, understanding intelligence as a form of governmental technique - a way of doing something - reveals an entirely novel way of thinking about and investigating its myriad (bistorical and contemporary) formations.
\end{abstract}

Keywords

Intelligence. Security. Government. Reason of state. Sovereignty

\section{Introdução}

Através da análise de documentos históricos primários e secundários, este artigo explora o papel de inteligência no início do governo moderno. Por largas razões de cunho prático - principalmente entre os quais se situa a disponibilidade de material original em inglês - o foco empírico está nos eventos da Commonwealth Inglesa. Conquanto os desenvolvimentos em inteligência (e governo) tenham sido realizados de 
forma diferente entre os Estados e territórios europeus ${ }^{3}$, a experiência inglesa representa uma significação histórica, um momento genealógico significativo específico do local na história mais ampla do poder e dos conhecimentos do Estado.

O trabalho convencional em inteligência tem tipicamente focado no desenvolvimento e nas atividades de instituições particulares (por exemplo, Deacon, 1970; Karalekas, 1977; Andrew, 1985; Darling, 1990; Cain, 1994), no papel desempenhado pela espionagem e outras operações secretas em conflito (Farago, 1962; Fergusson, 1984; Kahn, 1985), na história de práticas específicas como espionagem e abertura de carta (Seth, 1957; Deutsch, 1977; Ferris, 1989), ou no local da inteligência, e nos "ciclos" no processo de elaboração de políticas (Andrew \& Noakes, 1987; Hastedt, 1991; Codevilla, 1992).

Trabalhos acadêmicos mais recentes sobre relações internacionais, estudos de segurança e (socio)criminologia muitas vezes tomaram emprestado esse campo amplamente realista dos "estudos da inteligência". ${ }^{4}$

${ }^{3}$ Há evidências, por exemplo, de que, na virada do século XVIII, os franceses haviam superado os ingleses tanto em sigilo quanto em inteligência; "É claro que os franceses nos superam nessas duas coisas, sigilo e inteligência, e que podemos combiná-los nesses pontos é o projeto da [minha] proposta" (Defoe, 1704/1955, p. 265).

${ }_{4}$ Com algumas exceções notáveis (por exemplo, Der Derian, 1992; Rathmell, 2002; Neocleous, 2003; Dillon, 2003), estudos de inteligência muitas vezes adotaram uma abordagem bastante realista. O campo dos "estudos de inteligência" é composto principalmente por pesquisadores voltados para políticas e um número substancial de profissionais, jornalistas e "insiders". Um dos principais debates nos principais periódicos acadêmicos é como definir adequadamente a "inteligência", que é considerada um primeiro passo necessário no desenvolvimento de uma teoria universal da inteligência (ver, por exemplo, Scott \& Jackson, 2004). As três caracterizações mais comuns da inteligência se baseiam na histórica Inteligência Estratégica para a Política Mundial de Sherman Kent (1949). Para Kent, a inteligência pode ser entendida como: (i) um tipo de "conhecimento estratégico" (ou o que mais recentemente foi chamado de "informação avaliada"; ver também Gill, 2000, 2006; Aclin, 2010); (ii) as organizações que produzem esse conhecimento; ou, (iii) as atividades e métodos que essas organizações empregam ao 
Partindo de abordagens mais ortodoxas, a análise aqui deixa claro que em um determinado momento histórico - caracterizado por uma forma inicial de governo através da raison d'Etat ("razão de Estado"), rotinas generalizadas de sigilo e um campo pós-Westfália de competição europeia e (comercial) de intercâmbio entre Estados - a inteligência foi imaginada e apresentada como uma estratégica arte de governo para identificar riscos e oportunidades para o Estado moderno. Como o artigo demonstrará, reconceituando a inteligência como uma forma de técnica governamental uma forma de fazer algo - revelar-se-á uma maneira inteiramente nova de pensar e investigar sua trajetória histórica, suas diferentes práticas e procedimentos e suas muitas formações (passadas e presentes).

Como a evidência histórica deixa claro, logo após a Paz de Westfália em 1648, sob a posse do secretário de Estado Lorde Protetor Cromwell, John Thurloe, a inteligência era (re)imaginada como uma complexa arte de governo fundamental para os interesses do Estado. Isto é, a "inteligência" passou a ser entendida como algo mais do que informação, algo mais que notícias e algo mais que a sua coleta. Pelo contrário, foi cada vez mais articulada como um empreendimento prospectivo, prognóstico e estratégico para fornecer aos tomadores de decisão conhecimento necessário para governar de forma eficaz.

Em parte, isso significava descobrir tramas, conspirações e projetos perigosos contra o Estado, de modo a evitar a insurreição ou afastar a invasão. Mas, no entanto, também significava gerar, integrar e sintetizar todos os tipos de informação de maneira que expusessem boas e más possibilidades para o Estado; um processo que permitiu a visualização, cálculo e manipulação de tudo o que poderia representar algum perigo ou oportunidade para a Commonwealth. Isso significava

fazê-lo (ver também, Rathmell, 2002). Os tratamentos históricos geralmente começam com uma definição ou outra, e seguem mapeando o curso evolucionário de uma determinada instituição ou prática. 
desenvolver procedimentos não apenas para coletar informação, mas também para organizar, catalogar e agrupar diferentes materiais de forma sistemática.

O corpo de conhecimento assim produzido não se preocupava apenas com os movimentos e atividades de facções dissidentes e militares estrangeiros, mas também com as forças, recursos, alianças e até mesmo as intenções dos vizinhos europeus da Inglaterra. Isso possibilitou a antecipação e prevenção de riscos à paz, estabilidade e prosperidade, mas também com a identificação e manipulação de potenciais oportunidades de vantagem e ganho. Como isso sugere, a arte da inteligência executou um papel importante, ainda que em grande parte não reconhecido, na formação e no crescimento do início da modernidade do Estado, e - na medida em que também limita a capacidade dos rivais de dominar o comércio, controlar os mares e dominar as colônias - funcionava como uma característica constitutiva da estabilidade e equilíbrio europeus.

Com algumas poucas exceções (por exemplo, Miller, 1990), histórias de poder e conhecimento do Estado tiveram larga negligência no desenvolvimento do Estado moderno. No trabalho foucaultiano, de maneira mais geral, há uma preocupação com o liberalismo, a governamentalidade e (em uma menor extensão) a polícia, significando uma falta de atenção aos eventos anteriores à metade do século $18^{5}$. Isso pode ser uma consequência da ordem em que o trabalho de Foucault foi traduzido para o inglês, ou poderia resultar de sua afirmação de que a arte do governo não adquiriu seu "completo escopo e consistência" até a segunda metade do século XVIII (ver, por exemplo, Foucault, 2007, p. 101).

5 A ênfase na governamentalidade, liberalismo e polícia é evidente - e talvez em parte impulsionada - pela publicação das duas coleções inglesas mais influentes que tratam do trabalho de Foucault: O Efeito Foucault (ver Burchell et al., 1991) e Foucault e Razão Política (ver Barry et al., 1996). 
Qualquer que seja razão, a jornada da soberania e do direito divino dos reis ao liberalismo e ao governo dos homens e das coisas só é possível pela intervenção da raison d'Etat - uma forma de razão governamental que une a emergente arte do governo no fim do século XVI e XVII à secular soberania. De fato, o século XVII - o século da raison d'Etat - poderia ser precisamente descrito como um momento prolongado de transição durante o qual a arte do governo foi lenta e firmemente entrelaçada nos arranjos existentes; um processo que deu origem a muitas novas técnicas e aparelhos governamentais, e que desempenhou um papel importante na gradual ascensão da governamentalidade e da "governamentalização do Estado". Nisso reside a razão pela qual Foucault (2007, p. 286, 287) comparou o significado da raison d'Etat à revolução científica desencadeada por Galileu, Descartes e Kepler, e por que ele escolheu gastar tempo examinando sua emergência e transformação.

No final, e um pouco em desacordo com as preferências de pesquisa contemporâneas, ele concluiu que a aliança entre a "transição da rivalidade dos príncipes para a competição dos Estados é, sem dúvida, uma das mutações mais fundamentais em ambas as formas ocidentais de vida política e da forma histórica ocidental" (Foucault, 2007, p. 294).

\section{Governando através da Raison d'Etat}

Em suas palestras sobre Segurança, Território e População, Foucault deixou claro que, embora a lógica e as instituições da soberania tenham permanecido predominantes no século XVIII, textos teóricos do final do século XVI e início do século XVII procuraram construir uma forma primitiva e ainda bruta do governo nos arranjos políticos existentes. Enquanto os tratados escritos por Palazzo, Botero, La Perriere e outros suscitaram um "problema geral do governo", qualquer forma era vista como "interna ao Estado" e, portanto, suplementar a um tipo de governo que deve ser "aplicado ao Estado como um todo" (Foucault, 2007, p. 93). 
Este modo de governo específico e imperativo seria a responsabilidade de um soberano; uma "racionalidade, cálculo ou tipo de pensamento" através do qual o príncipe poderia governar "homens e coisas" dentro da estrutura da soberania (Foucault, 2007, p. 232). Tanto inédita quanto escandalosa, a teoria política da raison d'Etat ofereceu um diagrama em que o Estado era dotado de sua própria "razão"; um conhecimento necessário para encontrar, preservar e estender o Estado (Botero, 1606, p. 1). Este conhecimento seria um conhecimento de "coisas" ao invés de leis, das características, dimensões e forças do Estado (Foucault, 1991, p. 96), no qual o Estado também era entendido como um domínio complexo (ou jurisdição), um conjunto de leis, regras, costumes, instituições e pessoas. Ou seja, a teoria da raison d'Etat previa o Estado como princípio fundamental e objetivo último do governo apropriado. Como a "ideia de regulamentação" para a raison d'Etat, o Estado representou uma forma de repensar e reorganizar certos elementos e instituições já estabelecidos em "termos governamentais" (Foucault, 2007, p. 286). Como objetivo ou finalidade da raison d'Etat, o Estado também era o que deve resultar de uma intervenção governamental. ${ }^{6}$

Para garantir a constância de seu reinado, um príncipe teria que preservar e estender o Estado, uma tarefa que exigiria dele mais do que simplesmente aplicar a lei com justiça, sabedoria, prudência e misericórdia. Em vez disso, ele precisaria desenvolver e governar por meio de um conhecimento detalhado do Estado, de suas características e traços inerentes, e de como melhor preservar e aprimorar suas dimensões e forças. Investido com a raison d'Etat, “em vez de meramente controlar territórios e manter a lealdade dos sujeitos, o poder soberano moderno, cada vez mais preocupado em governar para o futuro, estabelece os

${ }^{6}$ Como Foucault (2007, p. 287) coloca, "o que a intervenção da raison d'Etat deve chegar é na integridade do Estado, sua conclusão, consolidação e seu restabelecimento, caso ele tenha sido comprometido, ou se uma revolução o derrubou ou momentaneamente suspendeu sua força e seus efeitos específicos". 
riscos" para o Estado (Valverde, 2007, p. 163). Esta temporária reorientação da soberania exigiria, por sua vez, novas técnicas para o "domínio intelectual" do Estado (Miller \& Rose, 1990), mas também como veremos em breve - dominar tudo o que pode ameaçar sua paz e estabilidade ou, de fato, contribuir para sua constância e crescimento.

Estatísticas, por exemplo, forneceriam um mecanismo através do qual as várias características do Estado poderiam ser categorizadas, quantificadas, medidas (e assim) conhecidas e manipuladas. Ao estabelecer diferentes categorias de medição e atribuindo valores numéricos a dimensões particulares ao Estado, as estatísticas também "constituíram" o Estado como uma entidade cognoscível e governável (ver, por exemplo, Hacking, 1982, 1990; Porter, 1986). E, no entanto, como os historiadores demonstraram, essa "ciência do Estado" (ou "aritmética política") não amadurece até a chegada do século XVIII, e os empreendimentos esporádicos antes disso chegavam a estimativas muito básicas para explicitar um propósito ou outro. ${ }^{7}$ De fato, não foi até a segunda metade do século XVIII que medidas mais rotineiras e sistemáticas acopladas com o surgimento da teoria das probabilidades, intensificou e proliferou a estatística em toda a Europa (ver, por exemplo, Ball, 2004; Hald, 2003; Stigler, 1986).

Para Foucault (2007, p. 101), esse atraso no desenvolvimento da estatística pode ser atribuído em parte às grandes crises que assolaram o século XVII, que garantiram a voracidade da soberania e "capturaram" a arte do governo.

"Basicamente, a arte de governo só poderia se
espalhar, refletir, assumir e aumentar suas
dimensões em um período de expansão livre das

${ }^{7}$ Pesquisas anteriores da Irlanda feitas por William Petty, por exemplo, foram realizadas para ajudar Cromwell a distribuir terras para seus soldados mais leais, enquanto os "testes de mortalidade" de John Graunt foram motivados por temores à praga. 
forças armadas, da economia e das políticas emergenciais que assolaram o século XVII, do começo ao fim. (Foucault, 2007, p. 101)"’8

E, no entanto, enquanto a soberania perdurava como a modalidade política dominante na Europa, o surgimento e proliferação da raison d'Etat gradualmente se entrelaça à arte do governo em instituições e arranjos soberanos. Ou seja, o governo "não ficou no ar" como ideia meramente teórica (Foucault, 2007, p. 100), e tinha correlações tangíveis no discurso político 9 e no exercício concreto. O principal entre estes foi uma ênfase discernível em preservar e proteger o Estado, evidente não só no trabalho de teóricos como Giovanni Botero ${ }^{10}$, mas também nos escritos mais práticos de figuras políticas como Sir Francis Bacon. ${ }^{11}$

Com efeito, enquanto o século XVIII marcaria a ascendência dos programas de expansão do Estado (um desenvolvimento independente da

${ }^{8}$ Entre elas, a Guerra dos Trinta Anos (1618-1648), revoltas camponesas generalizadas e revoltas urbanas em meados do século, e escassez prolífica e crises financeiras perto do fim do século.

${ }^{9}$ Foi notado na Câmara dos Comuns Inglesa em 1621, por exemplo, que "raciocinar sobre o Estado e a preservação do Estado é o que mais se encaixa neste lugar" (de Neocleous, 2003, p. 43). Da mesma forma, Chemnitz escreveu durante a Paz de Westfália (1647-48) que "todos os dias ouvimos um número infinito de pessoas falando de raison d'etat. Todos se juntam, aqueles enterrados no pó das escolas, bem como aqueles com responsabilidades de cargo público" (Thuau, 1966, p. 9-10, n. 2).

10 Para Botero, a preservação e a expansão de um Estado dependem da "paz e tranquilidade dos sujeitos", que deve ser assegurada evitando a "guerra travada por uma potência estrangeira", impedindo a "guerra civil, na qual os sujeitos lutam entre si" e impedir a "rebelião ou revolta, em que [os súditos] lutam contra o seu governante" (Botero, 1606, p. 12).

${ }^{11}$ Para Bacon - como Foucault deixa claro ao dissecar seu ensaio de 1625 "De sedições e problemas" - as forças que podem desestabilizar um Estado devem ser constantemente acompanhadas e evitadas. Os mais destrutivos destes são a sedição, a rebelião e a revolta aquelas causas "internas" de ruína que vêm de dentro do próprio Estado. 
ascensão da polícia), o século XVII foi aquele em que a "crise geral" (Trevor-Roper, 1959) garantiu a primazia do problema da preservação e da estabilidade do Estado. Na Europa, escritores e governantes tornaram-se cada vez mais preocupados com a "constante presença" de perigos como a sedição, a rebelião, a escassez, o colapso financeiro e a ruína do comércio (Foucault, 2007, p. 271). ${ }^{12}$ Neste ambiente de constantes ameaças, algumas calamidades principais pesaram na política de todas as monarquias ocidentais (Foucault, 2007, p. 101, 102), recaindo tanto sobre os discursos políticos quanto sobre o exercício prático, com características decididamente protetoras. Para os primeiros arquitetos da raison d'Etat, o problema de estender um Estado era, portanto, sempre suplementar à sua preservação: somente primeiro obtendo a paz e a estabilidade de um Estado - que, de outra forma, "não seria capaz de manter em si... por ora" (Palazzo, 1611, p. 14-16) - poderia ser este fortalecido e aprimorado. ${ }^{13} \mathrm{Em}$ termos práticos, isso significava desenvolver um conhecimento detalhado de todas aquelas "desagradáveis possibilidades" (Botero, 1606, p. 12) que poderiam afetar a constância do Estado, e que deveriam ser evitadas para prevenir "o ciclo de nascimento, crescimento, perfeição e decadência" que levou à queda muitos dos grandes impérios (Foucault, 2007, p. 289).

12 Embora a ameaça de invasão por um vizinho agressivo certamente nunca tenha desaparecido, muitos argumentaram que as causas mais insidiosas da ruína eram aquelas que vinham de dentro.

"[Quais] são as causas mais perniciosas [da ruína]? Sem dúvida, causas internas; pois raramente acontece de causas externas provocarem a queda de um Estado que ainda não foi corrompido internamente" (Botero, 1606, p. 5).

${ }_{13}$ Para Botero, "claramente é uma tarefa maior preservar um Estado, porque os assuntos humanos crescem e diminuem como que por uma lei de natureza" (1606, p. 5). Aqui, “... A raison d'Etat é essencialmente ... protetora ... o que está envolvido é essencialmente identificar o que é necessário e suficiente para que o Estado exista e se mantenha em sua integridade" (Foucault, 2007, p. 258). 
Na segunda metade do século XVII, no entanto, essa ênfase na preservação do Estado foi cada vez mais complementada por uma característica mais "discreta" e "aplicada" da raison d'Etat: a necessidade de melhorar ou estender as forças do Estado (Foucault, 2007, p. 288, 289). (A ideia que afirma que os Estados devem não somente perseverar, mas expandir-se estava claramente presente nos primeiros escritos, embora na prática funcionasse de maneira bastante subordinada e secundária ao problema de assegurar a estabilidade).

Após a Paz de Westfália de 1648, enquanto a questão da preservação do Estado não desaparecia, houve uma intensificação do problema de expansão do Estado. Os textos escritos por praticantes políticos em toda a Europa - tanto os que participaram nas assembleias como os que responderam aos tratados - começou a enfatizar a ideia de que, para se manter, o Estado deve também aumentar as suas "forças"; os aspectos intrínsecos do Estado, que incluíam seus recursos comerciais, naturais, recursos humanos, e de balança comercial (Foucault, 2007, p. 294). Se o Estado deveria ser imaginado como seu próprio fim - isto é, se é para ser organizado como referência a si mesmo - então sempre haverá uma pluralidade de Estados que competirão uns contra os outros, já que nenhuma unidade final é imaginada (como no Império todo-abrangente).

Um Estado irá, portanto, sempre existir em um campo de competição com outros, onde as fronteiras territoriais são fixas e onde a competição e a rivalidade são cada vez mais caracterizadas em termos econômicos e termos comerciais. Esta nova realidade para os territórios europeus se deveu, em parte, ao aumento das trocas comerciais e econômicas, e a uma luta perpétua pela "circulação monetária, conquista colonial e controle dos mares" (Foucault, 2007, p. 291). Assim - mesmo que, de uma maneira que permanece em grande parte subordinada ao problema da preservação do Estado - a raison d'Etat pós-Westfália é cada vez mais procurada para melhorar as forças do Estado e aperfeiçoar a sua posição competitiva vis a vis com os outros. 


\subsection{Das famílias reais aos escritórios administrativos do Estado}

Esta rearticulação dos fundamentos e meios para governar os primeiros Estados modernos foram, por sua vez, ligados ao desenvolvimento de um aparato administrativo e dos vários "escritórios de Estado" pela Europa. Como historiadores mostraram (ver, por exemplo, Evans, 1923), se um príncipe era visto como o "proprietário" de um reino pelas próprias leis da natureza, então nada mais do que a administração direta por seu comando (e através de sua família) era exigido dele. Para governar através da raison d'Etat, no entanto, seria necessário substituir os "métodos e instrumentos domésticos" por técnicas "administrativas", organizadas através de diferentes gabinetes de Estado que foram dotados de novos funcionários semiautônomos (Gunn, 1995, p. 4). Iniciando no começo do século XVII,

“(...) Um arranjo familiar informal, fluido e, por assim dizer, dependente do capricho do rei [foi substituído] por um conselho permanente, fixo e burocraticamente organizado de governo que, embora ainda totalmente dependente do rei em seu trabalho, havia se emancipado mesmo a partir do capricho do momento, bem como da estreita associação com o lar [real] (...)" (Elton, 1962, p. 344-345)

Foi precisamente através desse aparato administrativo que muitos novos conhecimentos e técnicas foram inventados e refinados,

"De acordo com uma visibilidade das minúcias das atividades da nação, planejando as calculadas técnicas através das quais esta visibilidade pode ser operada, e representando a nação por meio de 
uma variedade de conhecimentos ... um passo crucial na construção do "Estado" (...)"... (Miller, 1990, p. 323)

Como Peter Miller (1990) mostrou, por exemplo, no final do século XVII, o secretário de Estado francês para a Marinha, Superintendente de Comércio e Edifícios, e Controlador de Finanças JeanBaptiste Colbert estabeleceu uma série de procedimentos inovadores para gerenciar a relação entre o Estado francês e a empresa privada. Suas invenções específicas incluíram um conjunto de requisitos formais para manter os "livros de contas" (via Ordenação Legal de 1673), os mecanismos pedagógicos para instruir os comerciantes em procedimentos contábeis adequados (usando livros e manuais), e a representação de "contabilidade" em um discurso mais amplo de "ordem"; uma assembleia que elevou "a desejo de conhecer a nação e seus súditos em detalhes em um recurso essencial da regra política" (Miller, 1990, p. 322; ver também, Miller, 1986).

Tais empreendimentos eram frequentemente iniciados e dirigidos por Secretários de Estado da Europa ${ }^{14}$ e os principais funcionários do Estado ao longo do século XVII tiveram um crescente papel central diretivo em "políticas governamentais em quase todas as esferas, internas e no exterior" (Aubrey, 1990, p. 4). ${ }^{15} \mathrm{Na}$ França e na Espanha, as responsabilidades do Secretariado foram divididas entre vários escritórios

$14 \mathrm{Na}$ França, "les Secretaire d'Etat", na Espanha, "Secretarios de Estado y del Despacho".

15 "No século XVII os deveres administrativos realizados através do [gabinete do secretário]

aumentaram. Como o conselho privado declinou em importância como um corpo administrativo devido aos seus grandes números e às complexidades aumentadas do governo ... os secretários de Estado ... surgiram na vanguarda da vida política como chefes dos principais cargos executivos do Estado". (Higham, 1925, p. 366) 
diferentes, enquanto na Inglaterra um único Secretário era responsável por ambos os assuntos internos e externos. E, enquanto o Secretário Inglês era diretamente responsável perante a Rainha e o Conselho Privado (até a direção dos escritórios do Estado ser transferida para o Parlamento em 1688), desde o seu início, o escritório era em grande parte autônomo relativamente à família real e proporcionou um mandato extremamente amplo (Elton, 1963; Highham, 1925). ${ }^{16}$ Escolhendo o primeiro Secretário de Estado perto do final do seu reinado em 1603, a Rainha Elizabeth concedeu ao titular poderes e responsabilidades abrangentes, incluindo o gerenciamento da "religião" e das facções desordenadas dentro do reino, supervisionando os assuntos dos domínios ingleses do além-mar, supervisionando "Conselhos" estabelecidos nas "fronteiras do reino", defendendo o reino "por terra e por mar", monitorando a receita, a tributação, o comércio e as transferências, e organizando as relações diplomáticas e de "inteligência". ${ }^{17}$

\section{Reinventando a Inteligência I: Uma Vigilância Contínua de Pessoas e Coisas}

A partir de meados do século XVI, a palavra "inteligência" referiase não apenas a uma faculdade de compreensão individual, mas também de "informação verdadeira" ou "notícia"; fato confiável que poderia ser distinguido de boato ou rumor (de Johnson, 1773; ver também, Sabin, 1985, p. 3; Neocleous, 2003, p. 50-51). Nas primeiras décadas do século

${ }^{16}$ Foi dito que, a partir da nomeação do primeiro Secretário de Estado, a Inglaterra era governada "não por pares de linhagem antiga", mas por uma nova "classe cavalheiresca" de Cromwell, Sadler, Petres e Cecil (Dicey, 1760, p. 42; ver também Brown, 1968; Kleimola, 1987).

${ }^{17}$ Esses poderes foram extraídos do "Tratado sobre o cargo de Conselheiro e Secretário Principal por Sir Robert Beale para sua Majestade". Beale era o chefe de gabinete do secretário principal da rainha Elizabeth, Francis Walsingham. 
XVII, a coleta confiável de informação era uma das tarefas mais importantes do secretário (Fraser, 1956; Marshall, 1994, 2003).

Como o interlocutor oficial de notícias atualizadas e confiáveis, o Secretário Inglês foi responsável por aprender sobre eventos no continente e nos cantos distantes do reino, e regularmente transportava relatórios de inteligência para o Rei e seu conselho (do qual se dizia que um conde estava lá para "ornamento", um bispo por "razão de seu ofício", e o Secretário para "serviço e comunicação de inteligência"; Evans, 1923, p. 237). Para realizar essa tarefa, os primeiros secretários basearam-se em várias medidas muito informais, incluindo uma correspondência semirregular com Cônsules e representantes ingleses enviados para o exterior, a solicitação de relatórios de comandantes no Campo de Batalha, e pedidos de contas oficiais de emissários diplomáticos postados em tribunais estrangeiros. Na metade do século XVII, no entanto, os Tratados da Westfália reordenam relações internacionais e a instabilidade doméstica culminou com a decapitação do Rei Carlos I e a instalação do Protetorado, sendo que o secretário de Estado do Lord Protector Cromwell, John Thurloe determinou uma reestruturação radical da natureza da inteligência, e seu lugar e papel na garantia dos interesses do Estado.

Depois de mais de uma década de Guerra Civil envolvendo Inglaterra, Irlanda e Escócia, Oliver Cromwell dissolveu o Parlamento em 1653 e adquiriu os títulos vitalícios de "magistrado chefe" e de "administração do governo" via uma solução constitucional (o "Instrumento de Governo"). Sem sangue real, mas agindo como um rei em tudo menos no nome, Cromwell - um militar comandante do Novo Modelo de Exército - dependia fortemente do apoio militar para a sua autoridade política. Apesar deste apoio, no entanto, o Protetorado era tudo menos seguro, e enfrentou regularmente a oposição violenta de monarquistas que desejavam reinstalar a monarquia, "republicanos" que se opunham à ideia do governo militar (e da crescente autocracia de Cromwell), e um grande número de facções religiosas que clamavam por direitos iguais. Confrontado por uma instabilidade doméstica aguda, 
Cromwell pressionou incansavelmente por uma maior militarização do governo inglês, e em 1655 dividiu com sucesso a Inglaterra (e o País de Gales) em quinze distritos militares, cada um com seu próprio majorgeneral que garantiria a estabilidade local e o reforço do apoio ao regime do Protetorado.

Em Londres, no entanto, o Parlamento expressou preocupação com a crescente base militar do sistema de governo de Cromwell, e em 1656 - depois de rejeitar mais uma proposta para estabelecer um Exército permanente - os distritos militares foram dissolvidos. Com o aumento da instabilidade em diferentes frentes e com a resistência crescente a uma maior militarização em Londres, Cromwell recorreu a seu secretário de Estado, John Thurloe, que tinha uma visão totalmente diferente. Para Thurloe, se revoltas domésticas não poderiam ser impedidas com a devida aplicação da dissuasão militar, elas poderiam, em vez disso, ser previstas e evitadas com o uso adequado da inteligência. Com a bênção de Cromwell (e também com o seu financiamento), Thurloe começou a repensar e reconfigurar as formas que o escritório da Secretaria gerava, manipulava e explorava informações, estabelecendo um conjunto complexo e integrado de procedimentos para prever perigos para a Commonwealth.

Tendo trabalhado com o secretário Thurloe (e mais tarde com os Secretários Morice e Benett após o Restauração) ${ }^{18}$, Samuel Moreland delineou a abordagem de Thurloe em um "Discurso Breve sobre a Natureza e Razão da Inteligência", escrito em algum momento perto da virada do século XVII. ${ }^{19}$ A inteligência, afirma Moreland, é mais do que

${ }^{18}$ Durante todo o período da Restauração, que começou em 1660, depois que Carlos II foi (re)instalado como Rei da Inglaterra, havia dois secretários de Estado; uma para lidar com o norte da Europa (o Departamento do Norte) e outro para lidar com o sul da Europa. Os dois secretários compartilhavam a responsabilidade pelos assuntos domésticos e coloniais.

${ }^{19}$ Manuscrito da Biblioteca Britânica \# 47133. Egmont Papers (1576-1733), vol. CCXIV (ff. Ii + 276). 
informação, mais do que notícias, e exige mais do Secretário do que apenas coletar e divulgar fatos. Pelo contrário, deve ser entendido e praticado como uma complexa arte de governo que é fundamental para assegurar os interesses do Estado, mantendo a constância do "Governo" e a garantia de "sua pessoa real". ${ }^{20}$

Amizade, fraternidade e confiança são extremamente raros "entre homens" Moreland declarou, mas quase nunca pode existir entre Estados, já que estes são "governados inteiramente por máximas políticas, e movem-se em órbitas excêntricas" daqueles que são seus "Vizinhos e Aliados". Ou seja, os Estados sempre perseguirão seus próprios interesses e objetivos, procurando melhorar o seu próprio bem-estar e posição, mesmo em detrimento daqueles com quem chegaram a um acordo. Um príncipe deve, portanto, sempre desconfiar de seus súditos e guardar-se constantemente contra os "Heróis do povo" que "lançaram muitas vezes seus cavaleiros inábeis"21, e também deve duvidar de seus vizinhos, mesmo aqueles com quem ele tem algum acordo. Ao invés de colocar sua fé em tratados e alianças (que são facilmente quebrados), ele deveria procurar descobrir as mentes e intenções de seus vizinhos, sempre olhando à frente e raciocinando como um "astuto jogador". Ao fazê-lo, ele deve desenvolver esforços para "saber que cartas" estão em suas mãos para que ele possa jogar a sua "com a maior vantagem". A Inteligência praticada corretamente irá expor a verdadeira natureza de seus súditos e seus vizinhos - seus interesses, suas ambições e suas formas - fornecendo-lhe a "clareza" e a "previsão" necessárias para governar adequadamente em um ambiente incerto e anárquico; é a "mãe de prevenção", "essencial às artes do governo" ${ }^{22}$, cuja falta "um Príncipe pode perder sua coroa ou vida".

${ }^{20}$ Moreland está escrevendo depois da Restauração da monarquia inglesa.

${ }^{21}$ Moreland está se referindo aqui à decapitação de Carlos I em 1649.

22 Isto é de uma carta escrita por Isaac Basire para Sir Phillip Musgrave, em 17 de maio de 1665. Biblioteca da Universidade de Durham, Cosin Letter Books, 1 (b): 132. 


\subsection{Recrutando "Sentinelas"}

Uma dimensão importante para esta arte da inteligência é o que Moreland chamou de "uma visão constante de tudo o que se passa em qualquer momento", uma espécie de vigilância perpétua de pessoas e coisas. Sob o mandato do subsecretário Thurloe, sobre o qual Moreland discorreu em seu discurso, isto foi conquistado por três instrumentos primários: (i) uma rede expansiva de espiões e informantes (ou "Centinels"); (ii) controle centralizado e manipulação dos correios; e (iii) um sistema "universal" de correspondência. O efeito de tais medidas foi que,

"Sob seus olhos em constante análise, passaramse relatos de eventos grandes e pequenos, que ocorreram na Inglaterra ou nas capitais e outras grandes cidades da Europa ... todas as notícias tiveram o seu significado para ele, se foi a reação dos cidadãos de Londres para a adesão do Protetor, um ministro que pregava publicamente contra o aumento da tributação, ou o número e disposição de exércitos e frotas inimigas" (Citação em Hobman, 1961, p. 14).

A mais documentada dessas iniciativas foi a utilização de espiões e informantes para aprender sobre as atividades, movimentos e planos de facções dissidentes e seitas religiosas tanto na Inglaterra quanto no continente (especialmente na França, onde o filho de Carlos I e seu leal marquês viviam no exílio). ${ }^{23} \mathrm{E}$, no entanto, Thurloe também recrutou

23 “Assim fez o Sr. Cockin, um pregador de uma Congregação, descobrir, por vários anos para o Sr. Thurloe (embora com todo sigilo imaginável) todos os procedimentos e consultas de seus irmãos Independentes, e tinha um salário de 500 libras por ano por suas dores; e assim fez Sir Richard Willis trair todos os Conselhos e compromissos dos 
informantes que enviariam informações de terras e territórios muito distantes, incluindo relatórios sobre as deliberações de Tribunais Reais e relatos detalhados de eventos em portos, cidades e aldeias vitais.

Enquanto alguns se apresentariam espontaneamente (oferecendolhe o serviço em troca de pagamento; ver, por exemplo, Aubrey, 1990, p. 94), o Secretário também começou a recrutar homens de qualidade que ele considerava com boas conexões, bem colocados e provavelmente passíveis de aceitar incentivo financeiro. Citando esses esforços tipicamente clandestinos, John Wildman - uma figura solidária e política que eventualmente ocupou o cargo de General dos Correios entre 1689-1691 mais tarde defendeu que Charles II seguisse de perto o modelo de Thurloe, e que

“(...) todos os meios imagináveis podem ser usados para ganhar mais de dois ou três membros principais de cada facção reinante...quem pode separadamente, (para que eles possam checar uns aos outros para a descoberta mais segura da verdade) e com todo o tipo de sigilo, manter uma correspondência constante com a sua honra, e ... prestar-lhe contas exatamente do que sempre passa ou é transacionado em tais reuniões, então você será capaz de esmagá-los em todas as formas, e impedi-los de chegar a qualquer maturidade (...)" ${ }^{24}$

royallistas" (do discurso breve de John Wildman sobre o negócio da inteligência, impresso em Firth, 1898).

${ }^{24}$ Isto foi retirado de "Um breve discurso sobre o negócio da inteligência e como ele pode ser administrado com a maior vantagem", escrito em algum momento durante a Restauração, provavelmente por John Wildman (impresso em Firth, 1898). 
Para organizar e gerenciar sua crescente rede de espiões, Thurloe criou um esquema contábil para manter registros escritos de "desembolsos de inteligência" que seu escritório pagou. Enquanto os seus antecessores haviam mantido apenas livros de contas esporádicos, Thurloe reteve transcrições listadas de seus diferentes informantes (normalmente organizadas pelo codinome ou pseudônimo), juntamente com a quantia que eles foram pagos e quando. Ao manter esses registros, o seu gabinete foi capaz de garantir não só uma gestão centralizada e um sistema organizado de contabilidade financeira, mas também um meio de avaliar a constância, confiabilidade e valor de suas diferentes fontes. Um grau sem precedentes de organização e sistematização na gestão de espiões e informantes levou alguns a afirmar que estava em vigor em seu escritório o primeiro "Quartel-General de Londres" para um "moderno Serviço de Inteligência" (Hobman, 1961, p. 23; ver também Helt, 1994).

\subsection{Equipando a "Torre de vigia"}

Menos conhecido que seu uso de espiões e informantes são os incansáveis esforços de Thurloe para expandir e integrar os correios no interior e no estrangeiro, e estabelecer uma estação de correios única em Londres. Em meados da década de 1650, ele conseguiu mesclar as diferentes transmissões postais ao longo da Commonwealth e trazer todo o aparato sob o controle do secretariado. Isso permitiu a nomeação de abridores de cartas especiais em Londres que secretamente vasculhariam e copiariam correspondências antes de enviá-las a seu destino.

Este segundo instrumento para garantir uma visão constante das coisas - que Samuel Moreland mais tarde se referiu como sendo uma "Sentinela" permanente - baseava-se na noção de que cartas e pacotes privados forneceriam ao Secretário um fluxo contínuo e confiável de informações que os correspondentes assumiam como privadas e que, portanto, incluiriam informações valiosas. Depois da restauração, John 
Wildman celebrou a administração de Thurloe dos correios, enfatizando seu valor para assegurar a paz e a estabilidade contínuas;

"Outra grande trama ... foi cuidadosamente
observar o General, e suas muitas preocupações
com a paz pública e que o mesmo seja feito agora;
pois através deste escritório são transmitidas todas
as doenças venenosas da Cidade para todo o
reino... [naquela época]...havia quase todas as
cartas pós-noite interceptadas (...)" "25

A prática de interceptar cartas não era, naturalmente, particularmente nova. Francis Walsingham, por exemplo, (principal secretário da rainha Elizabeth) apreendeu cartas e pacotes enquanto tentava enraizar o catolicismo na Inglaterra. E, no entanto, em vez de limitar a circulação postal e intermitentemente apreender pacotes (quando ele tinha razão para suspeitar de algum plano ou conspiração), Thurloe fez um lobby extensivamente para a expansão das rotas postais, a integração dos diferentes meios de transmissão em um sistema comum, e a centralização do controle sobre todo o aparato em Londres. Isto lhe permitiu capitalizar o aumento da circulação, instituindo procedimentos regulares e sistemáticos para abrir, ler e copiar correspondências, e para evitar o problema enfrentado por seus predecessores de tentar convencer os mensageiros individuais a entregar seus pacotes.

Enquanto os Secretários anteriores foram forçados a tentar pressionar os correios para entregar cartas aparentemente suspeitas, e embora em 1582 isso tenha ajudado Francis Walsingham a descobrir um plano para instalar Maria, Rainha dos Escoceses, no trono, Thurloe

${ }^{25}$ Do breve discurso de John Wildman sobre o negócio da inteligência (impresso em Firth, 1898). 
acreditava que sem o poder formal sobre os funcionários dos correios seria impossível adquirir a influência plena e necessária sobre eles. ${ }^{26}$ Como resultado, em 1655, depois de pressionar o Parlamento através das "razões de Estado", ele assegurou o cargo de Chefe dos Correios para si mesmo uma nomeação que anteriormente só tinha sido realizada por autorização privada. Isto lhe concedeu os poderes de ambos: Secretário de Estado e Chefe dos Correios, um movimento que envolveu o sistema Inglês de correios no aparelho administrativo e permitiu Thurloe instituir mudanças generalizadas.

Em 1657 uma lei para um único sistema consolidado de postagem inglês, escocês e irlandês foi promulgada - uma lei baseada no argumento decisivo de Thurloe de que um correio estatizado era vital para "prevenir projetos perigosos contra o Estado" (ver Firth, 1897; Joyce, 1893; Turner, 1918). A legislação subsequente no final dos anos 1650 e início dos anos 1660 reforçou e estendeu este controle sobre o escritório dos correios, fornecendo ao Secretário poderes legais para o "levantamento e inspeção de todas as cartas", "audiência e determinação" de reclamações contra o escritório, e controle sobre a nomeação e remoção de carteiros e outros funcionários (o que permitia a demissão daqueles que não cooperavam ou "contra quem foi feita a exceção"). ${ }^{27}$ Sob este novo arranjo, Thurloe foi capaz de manter os seus dedos no "pulso de todo movimento político" (Hyde, 1894, p. 238), formalizando um dos principais instrumentos de seu "monopólio preventivo" (Whyman, 2000, p. 3) sobre a informação.

Por sua ordem, um grupo especial de deputados e assistentes incluindo John Wallis, Isaac Dorislaus e o próprio Sir Samuel Moreland (Bond, 1955; Whyman, 2000) - foi instruído a "residir constantemente" em uma sala privada ao lado do escritório de correspondência estrangeira em Londres, onde eles iriam abrir, ler e copiar a correspondência das 23 horas

${ }^{26}$ Do relato de Thomas Scot sobre suas ações como um intelectual durante o período conhecido como "Commonwealth" (impresso em Firth, 1897).

${ }^{27}$ Da locação de 1663 do escritório para Daniel O'Neil. 
até às "3 ou 4 da manhã, que era o período usual de calar os homens". ${ }^{28}$ Ainda, cartas "de todos os Embaixadores e ministros públicos foram constantemente abertas, e cópias delas foram enviadas ao Sr. Thurloe" ${ }^{29}$, os abridores de cartas tinham de ser diligentes, hábeis e discretos, resselar perfeitamente os pacotes para evitar ser descobertos.

O medo era o de que se os abridores de cartas fossem descobertos, as pessoas deixariam de usar o correio - algo que teria um impacto significativo sobre a capacidade de Thurloe para reunir precisamente o tipo de informação que ele procurava. ${ }^{30}$ Após a integração do interior e dos transmissores estrangeiros, Thurloe também nomeou um grupo de funcionários multilíngues para "extrair, copiar, traduzir, etc. todas as questões de correspondência" 31 que entravam e saíam da Commonwealth. Isso lhe forneceu todo o tipo de correspondência de lugares tão distantes quanto o Báltico, a Itália, a Espanha, França, Moscou e dos Estados alemães, incluindo cartas particulares enviadas entre parentes, amigos, mercadores e poderosos nobres, comunicados oficiais e "instruções" passadas aos embaixadores, ministros e outros funcionários do Estado, e um fluxo regular de "gazettes" e "boletins informativos" (panfletos de

${ }^{28}$ Do discurso breve de John Wildman sobre o negócio da inteligência (impresso em Firth, 1898). Veja também a "confissão" de Thomas Scot (impressa em Firth, 1897) e Hobman (1961, p. 19).

${ }^{29}$ Do breve discurso de John Wildman sobre o negócio da inteligência (impresso em Firth, 1898). Veja também a "confissão" de Thomas Scot (impressa em Firth, 1897).

${ }^{30}$ Depois de tomar conhecimento da prática, um funcionário francês aconselhou sua corte em Paris a considerar cuidadosamente a correspondência futura, como os ingleses haviam desenvolvido,

“... Truques para abrir cartas com mais habilidade do que em qualquer lugar do mundo. Alguns chegam a pensar que é a coisa certa e que não é possível ser um grande estadista sem adulterar os pacotes" (de documentos impressos em Jusserand, 1892, p. 50).

31 De um documento encontrado no escritório dos Secretários, agora na Biblioteca Britânica (ver também Fraser, 1956, p. 59). 
autoria estatal impressos em massa que informavam nomeações oficiais, vitórias militares e procedimentos parlamentares, entre outras coisas).

Após a restauração de Carlos II em 1660, a prática da abertura de cartas foi amplamente condenada como mais uma prova da perversão do Protetorado de Cromwell. Para aliviar os medos generalizados de que os pacotes privados estavam demorando a ser entregues pois estariam sendo lidos e copiados, o Chefe dos Correios pós-restaurador e pós-Restauração, Henry Bishop, inventou um processo de "carimbagem de cartas" que imprimiu na frente de cada pacote a data em que foi recebido pelo escritório, assegurando que suas cartas não estavam sendo enviadas em atraso (o "carimbo postal" de Bishop pode ter sido o primeiro selo usado na Inglaterra).

Os secretários de Estado Nicholas, Morice e Benett, no entanto, estavam bastante enamorados com a eficiência e a utilidade do sistema de Thurloe, e a prática de abertura de cartas, em sua maioria, continuou (embora com mais discrição). No "Memorial sobre o Governo dos Correios", escrito para Carlos II em algum momento entre 1660 e 1666, Thomas Ibson argumentou que, dadas as "diversidades de animosidades" e diferentes "seitas" atuando dentro das "arcadas" do reino - "sem uma correspondência geral este nunca poderia prosperar - não há local ou escritório "mais digno de...inspeção, do que os Correios". De fato, enquanto a informação acumulada pela abertura de cartas particulares cobria muito mais do que as atividades de facções e seitas rebeldes, a prática era mais frequentemente recomendada e defendida com base no fato de ser vital para proteger o Estado contra elementos subversivos e traidores. Em 1677, o secretário Henry Coventry argumentou que, precisamente por essa razão, "a abertura de cartas" é "o que nenhum homem pode justificar, senão pela razão de Estado" (impresso em Highman, 1932, p. 212) e somente "um Secretário de Estado pode 
demandar um relatório da quantidade de cartas que entram nos correios 1132

No entanto, como John Wildman observou após a Restauração, o problema mais difícil para Thurloe (assim como para seus sucessores) era a rede de mensageiros não-oficiais e "correios de pé" que distribuíam pacotes em Londres e arredores por uma taxa..$^{33}$ Apesar de muito esforço, Thurloe nunca foi capaz de trazer essas transportadoras privadas sob seu controle, e muitas vezes o melhor que conseguiu foi

"imediatamente antes de uma ascensão ... enviar 2 ou 3 Mensageiros de seu Conselho para apreender e levar consigo todos os pacquetts e cartas que eles poderiam encontrar com os transportadores e correios ao longo da cidade, que eram mais comumente jogados de lado e nunca mais voltavam (...)"

Isso, Wildman argumentou, era deixar as coisas atrasadas "quando as tramas não eram apenas artificiais, mas prontas para ser colocadas em ação". Isto também teve o infeliz efeito de muitas vezes levar à "absoluta anulação de várias pessoas pobres" que tiveram suas cartas de procuração, letras de câmbio e cartas particulares perdidas para sempre. A sua solução para este problema foi estabelecer um complexo sistema de licenciamento através de uma nova "Comissão" que iria

“(...) tomar conhecimento tanto dos nomes como
dos habituais locais de alojamento de todos os

32 Extraído de uma carta do Secretário Coventry para Lord Arlington, 18 de setembro de 1677.

${ }_{33}$ Do breve discurso de John Wildman sobre o negócio da inteligência (impresso em Firth, 1898). 
transportadores e correios comuns na ou sobre a cidade, assim como a dita pessoa com poderes para administrar um juramento de fidelidade ao serviço de sua Majestade, e então dar-lhes licenças para que possam ter algum tipo de influência sobre eles, e a melhor oportunidade de tratar e conviver com eles em particular, fazê-los dispostos a enviar para ele [as cartas] seladas cerca de 2 horas antes de sua partida (...)”

\subsection{Uma "Correspondência Universal"}

A colonização de Thurloe no correio permitiu que ele estabelecesse o que Moreland depois descreveu como um sistema universal de correspondência ${ }^{34}$ que abrangia uma variedade de contatos em quase todo território e reino da Europa. As cartas cada vez mais regulares enviadas entre o gabinete da Secretaria em Londres e os embaixadores ingleses postadas no exterior se tornaram apenas uma faceta de uma rede de comunicação muito mais ampla e expansiva, incluindo muitos que enviavam à Thurloe pacotes com grande risco pessoal. ${ }^{35}$ Estes incluíam mercadores viajantes, ministros e nobres, "amigos da coroa" residentes no estrangeiro, contatos anônimos em portos, vilarejos e cidades europeias, e

${ }^{34}$ Do discurso de Moreland; Manuscrito da Biblioteca Britânica \# 47133. Egmont Papers (1576-1733), vol. CCXIV (ff. Ii + 276).

35 Para proteger suas identidades, “a maneira como ele se correspondia com os espiões do além-mar, ou dos países daqui da Inglaterra era assim: o dito Moreland dava-lhes alguns endereços falsos para os quais dirigiam todas as suas cartas ... e ao mesmo tempo enviava o mesmo endereço ao Sr. Dorislaus no correio para colocá-lo em sua lista, que assim quando ele abrisse a correspondência, e encontrasse o endereço, ele saberia que deve enviá-las". 
um número de pessoas "influentes" em tribunais distantes (ver, por exemplo, Hobman, 1961).

Outros casos regulares incluíam "Tenentes e pessoas tituladas" nos condados ingleses, oficiais de alfândega locais, armazenistas navais, agentes dos correios e outros administradores de baixo nível, comandantes de exército no campo, vários eruditos proeminentes e uma gama de pessoas "não identificadas". ${ }^{36}$ Era indispensável para sua teia de correspondência um grupo de "intelectuais" profissionais; bem conectados, bem informados, "Senhores da qualidade" que forneciam informações por uma taxa prescrita (ou ocasionalmente contrato a termo) (ver, por exemplo, Birch, 1849). Embora os intelectuais - como espiões - frequentemente trabalhassem discretamente e vendessem informações para obter lucro, eles foram percebidos como escritores "profissionais" de notícias cujas contas eram muito mais confiáveis (e, portanto, muito mais valiosas) do que as de espiões e "vira-casacas". ${ }^{37} \mathrm{Na}$ verdade, não era incomum para ricos comerciantes, aristocratas e até mesmo bons ministros de alto escalão contratar seus próprios intelectuais, e Thurloe certamente não foi o primeiro a envolver esses serviços, pois no momento da Restauração, foi dito que Henry Muddiman - que assistiu ao então secretário Nicholas com o "sistema de cartas" - tinha herdado a mais difundida rede na Europa (Muddiman, 1923).

Enquanto os diferentes correspondentes de Thurloe pediam notícias da Inglaterra, ele era normalmente contrário em compartilhar algo mais do que um breve relato de eventos e, na maioria das vezes nem isso o seu sistema era em grande parte unidirecional. Entretanto, restrições

${ }^{36}$ Do relato de Thomas Scot de suas ações como um agente de inteligência durante a Commonwealth (do Discurso de Wildman, impresso em Firth, 1897).

${ }^{37}$ Em grande parte, em virtude de sua posição social superior. Uma coleção dos tipos de cartas escritas por intelectuais foi compilada por Thomas Birch, que as considerou um relato mais interessante da história do que os documentos oficiais do Estado (ver Birch, 1849). 
financeiras e uma falha maciça do aparato de inteligência durante a segunda guerra anglo-holandesa, forçaram os secretários Morice e Benett a reconsiderar essa prática e fazer algumas mudanças em como os seus escritórios compartilhavam a informação.

Após um encontro naval desastroso com os holandeses em 1666 (em que a maioria da Frota inglesa foi destruída), um inquérito parlamentar liderado pelo príncipe Rupert questionou Morice e Benett por que eles tinham subestimado o tamanho da frota holandesa e erroneamente esperado os franceses para se juntar à batalha. ( $\mathrm{O}$ príncipe havia elaborado sua estratégia com base em suas avaliações, e assim, dividiu fatalmente a frota inglesa). Ambos os secretários alegaram "falta de inteligência do estrangeiro", que, segundo eles, foi o resultado de orçamentos cada vez mais limitados. Tendo sido recusado mais dinheiro em um período de restrição financeira significativa, sua solução bastante inventiva era em vez disso, oferecer informações próprias em troca. Imediatamente eles tiveram

"(...) um boletim informativo que retirava a nata das cartas semanais de cerca de cinquenta correspondentes espalhados por todo o reino, acrescentou notícias de seus próprios como nomeações oficiais e procedimentos parlamentares, empregou quatro ou cinco funcionários para multiplicar a cópia em manuscrito, e enviar esses boletins semanalmente como quid pro quo para todos ... correspondentes e para um número substancial de "amigos do campo" (Fraser 1956:28)".

Bem antes do final do século 17, este sistema inovador de troca de informações bidirecional tornou-se "indispensável" ao aparato de inteligência, "sem o qual não poderia continuar" (Secretário Williamson c. 
1676). Como os boletins dos Secretários se tornaram extremamente desejáveis na Inglaterra e no continente, sua gama de correspondentes não só foi mantida, mas substancialmente aumentada.

\subsection{Inteligência e o Problema do Sigilo}

Como esses três instrumentos sugerem, a visão de Thurloe para a inteligência foi ordenada não apenas sob os requisitos da raison d'Etat e das tecnologias disponíveis da época, mas por amplas rotinas de sigilo que dificultavam a aprendizagem de tudo o que ele precisava saber. Quase todos os textos sobre raison d'Etat do século XVII asseveravam que um conhecimento detalhado do próprio Estado e de outros Estados era vital para manter a força e a estabilidade (ver também Foucault, 1988/1981, p. 151; Neocleous, 2003, p. 46).

No entanto, tal conhecimento era "apenas um instrumento de governo na condição de não ser divulgado" (Foucault, 2007, p. 275). Em outras palavras, para que o conhecimento exigido pela raison d'Etat fosse eficaz, deveria ser mantido em segredo, "[n]o tempo em que isso foi uma parte explícita da raison d'Etat chamada arcana imperii, os segredos do poder" (Foucault, 2007, p. 275). Em particular, os Estados "inimigos e rivais" não devem ser capazes de aprender os reais recursos disponíveis (Foucault, 2007, p. 275), uma vez que "quanto mais as forças do Estado são desconhecidas, mais elas merecem respeito. ${ }^{38}$ Seguindo a Paz da Westfália, essa necessidade de sigilo só se intensificou como a perspectiva do supremo domínio imperial via expansão territorial sem fim que deu lugar a um campo de Estados relativamente fixos e ainda agressivamente competitivos.

38 Traduzido do texto anônimo de 1736: "Discours historique a Monseigneur le Dauphin sur le Gouvernement interieur du Royaume"; veja Brian (1994, p. 155). 
Para manter a estabilidade e o equilíbrio, esses Estados teriam que competir de forma que aumentassem suas forças, mas não trouxessem ruína dos outros ou a ruptura do todo (ver Foucault, 2007, p. 297-300). Como resultado, a raison $d^{\prime}$ Etat foi cada vez mais delineada em "termos diplomáticos", "essencialmente definida pela constituição de uma Europa" (Foucault, 2007, p. 300), e começou a fazer uso de vários mecanismos ${ }^{39}$ que permitiriam a concorrência enquanto mantinham a "paz através da pluralidade". Foucault referiu-se a um desses mecanismos como um "aparato de informação (apparei $)^{440}$, uma dimensão que era precisamente sigilosa, ou mais especificamente, mantinha oculto o conhecimento que o Estado deve desenvolver. Como ele disse, isso significará

"Conhecendo as próprias forças (e ainda as escondendo), conhecendo as dos outros, aliados e adversários, e escondendo o fato de que alguém os conhece. (Foucault, 2007, p. 306, nota de rodapé)".

Na prática, o imperativo do sigilo provocou uma série de restrições à circulação de informações, particularmente aquelas que poderiam expor as características e forças reais do Estado, incluindo sua riqueza, força militar, alianças e acordos comerciais, e seus planos de crescimento. Isto foi alcançado, por exemplo, mantendo-se um olhar atento aos enviados estrangeiros e embaixadores que "são em sua maior parte grandes

${ }^{39}$ Esses instrumentos incluíam uma nova forma de guerra "diplomática", um sistema de diplomacia que buscava preservar a "maior estabilidade possível", a criação de exércitos permanentes e um aparato de informação (ver Foucault, 2007, p. 301-306).

40 Essa quarta dimensão do aparato militar-diplomático é mencionada apenas no manuscrito original para 22 de março e, por alguma razão, não é retomada na palestra (ver Foucault, 2007, p. 306 e nota de rodapé). 
espiões"41, e implementando uma "codificação precisa" do que poderia ou não ser publicado (ver Foucault, 2007, p. 275).

Em Londres, ambas as tarefas foram realizadas por muitos deputados de Thurloe, e no interesse do sigilo, ele foi até mesmo "bastante preparado para privar [...] o público de um relato básico de eventos domésticos" (Fraser, 1956, p. 29). Como em outros lugares da Europa, controles rigorosos de impressão eram comuns durante o século XVII, e foram tipicamente complementados pela rigorosa censura de quaisquer panfletos ou boletins informativos que deveriam ser distribuídos. Sucessivos secretários ingleses lutaram implacavelmente contra qualquer tipo de imprensa pública ou gratuita, e passavam a maior parte do tempo suprimindo impressões privadas (muitas vezes através de esquemas complexos de licenciamento que representavam monopólios virtuais de Estado). ${ }^{42}$ Enquanto alguns dos oficiais de Thurloe fizeram um grande esforço para reprimir o material de impressão não licenciado ${ }^{43}$, a Lei de Licenciamento de 1662 tornou isso uma tarefa um pouco menos onerosa, como se um monopólio de impressão Secretarial fosse formalizado em lei.

${ }^{41}$ Como John Wildman observou em seu discurso sobre inteligência: "outra intriga no negócio da Inteligência é esta: todos os Embaixadores e Ministros Públicos, são na maior parte do tempo, grandes espiões, e um dos serviços mais aceitáveis que eles podem fazer com seus mestres é ganhar para alguns dos Ministros, Conselheiros, Secretários, ou outros Oficiais daquele Reino ou Estado onde residam. E, portanto, deve haver um relógio apertado sobre eles, e suas cartas constantemente abertas, e não era difícil colocar em suas casas por algum outro lado à distância alguma pessoa de confiança, que pudesse ser entretida como seus servos domésticos, e isso significa descobrir quem entra nas nossas portas dos fundos na noite".

42 A luta entre os impressores privados e os Secretários de Estado ingleses tem sido extensamente abordada por Levy (1985) e Stephens (2007).

${ }^{43}$ Como Thomas Scot confessou após a Restauração: "eu tinha muito a fazer e muito do meu tempo foi gasto ... em suprimir o crescente número de panfletários, que mais cedo ou mais tarde eu sempre tive em meu poder" (impresso em Firth, 1897, p. 121). 
"Este Estado de coisas fez a London Gazette (um jornal impresso, também sob a supervisão do Secretário de Estado, e não contendo notícias domésticas), a única fonte licenciada de notícias para o público em geral entre 1660 e 1688 (Couvee, 1956, p. 251)". ${ }^{44}$

Embora as restrições sobre materiais impressos não tenha sido nada de novo no século XVII, ${ }^{45}$ a razão para proibir a impressão não oficial sofreu uma mudança perceptível a partir da necessidade de preservar a relação entre os governantes e as "vertiginosas multidões", ${ }^{46}$ e

${ }^{44}$ Depois da Revolução Inglesa de 1688, o controle estatal sobre a impressão era mais difícil de justificar e sustentar, pois em 1689-1690, vários panfletos privados e diários publicamente disponíveis surgiram em Londres e arredores. A ofensiva da imprensa depois da Revolução foi facilitada tanto pelo Penny Post (originalmente estabelecido em Londres em 1680, e por muito tempo considerado uma ameaça ao controle de secretaria sobre material impresso) quanto pela abertura de 'cafeterias' nas quais os clientes se reuniam para conversar, e em que os intelectuais profissionais exerciam seu ofício (Fraser, 1956). Com a ascensão de Guilherme e Maria em 1688, o monopólio da imprensa que os secretários desfrutaram se desintegrou com a entrega de licenças privadas e a "imprensa privada" começou a surgir (Williams, 1908).

45 As proibições datam de pelo menos do início de 1500, e algumas até mesmo proibiam "notícias faladas". Em 1538, o rei Henrique VIII decretou que todos os impressos tinham de ser aprovados pelo Conselho Privado e, em 1557, o Queen Mary concedeu uma Carta Real à Companhia de Papeleiros que restringia o direito de possuir uma prensa. Como Clarke (2004, p. 13) observa, "publicar notícias era visto como uma interferência nos assuntos de Estado que exporiam o funcionamento do governo à vertiginosa multidão e minaria a relação entre governantes e governados. Até mesmo as "notícias faladas" [...] foram proibidas pelas proclamações de 1547 e 1549 de Edward VI. A única forma de informação impressa disponível para grande parte do século 16 era a "relação", uma narrativa de um único evento tipicamente de autoria do soberano, gabando-se da vitória militar ou descrevendo um item de "novidades maravilhosas e estranhas". (Clarke, 2004, p. 13)

46 Ver nota 45. 
também da necessidade de assegurar interesses e segurança do Estado. As medidas de Thurloe para garantir o sigilo também envolveram o monitoramento da liberação de informações de seus escritórios, certificando-se de que nada foi compartilhado com ninguém além das informações consideradas essenciais para a sua missão. Os relatórios de diferentes informantes, espiões e correspondentes foram cuidadosamente protegidos e guardados em sua sede em Londres, enquanto a matéria foi divulgada apenas de forma censurada e sintetizada aos funcionários, ministros e/ou comandantes militares que foram considerados como tendo alguma necessidade particular de saber. Em despachos secretos enviados diretamente de seu escritório, por correio e sob a guarda armada, pacotes individualmente adaptados foram enviados para aqueles que ele decidiu que estavam precisando de um pouco de informação em particular, geralmente correlacionados a uma área de responsabilidade administrativa ou militar.

Em correspondência com suas fontes na Inglaterra e no exterior, ele também deixou claro que eles nunca deveriam compartilhar o que aprenderam com qualquer outra pessoa; "a principal consideração era de que a melhor inteligência só poderia ser obtida...se suas notícias fossem mantidas exclusivamente para eles mesmos" (Fraser, 1956, p. 29). Isto é, quanto mais informação era compartilhada, menos valiosa ela se tornava, e menos vantagem ela oferecia. Após a Restauração, e apesar dos orçamentos menores para a inteligência, os secretários Morice e Bennett levaram adiante muitas dessas rotinas, variações das quais eram também evidentes em outros Estados europeus, e que perduraram nas últimas décadas do século XVIII (Brian, 1994).

Um dos efeitos de tal sigilo generalizado, no entanto - que não era apenas endêmico à raison d'Etat, mas uma característica constitutiva da competição e do equilíbrio europeus - foi uma intensificação no problema de adquirir o conhecimento que outros procuravam manter oculto. Isso se tornou ainda mais complexo em um ambiente de rivalidade cada vez mais baseado na economia e no comércio, no qual quanto mais conhecimento 
um Estado poderia recorrer ao negociar as vicissitudes das trocas comerciais, mais vantagem teria em garantir seus próprios interesses. Em outras palavras, o concorrente precisa desenvolver o conhecimento e manter o sigilo - em um campo de múltiplos Estados competitivos, cada qual com exatamente os mesmos requisitos - gerando uma problemática única na qual os Estados precisavam aprender sobre os outros enquanto se esforçavam para manter o conhecimento de si mesmos escondido.

De fato, é precisamente essa problemática que ajudou a tornar necessária a arte da inteligência, e lhe deu definição e forma particulares. À medida que os Estados melhoraram suas capacidades de aprender coisas sobre os outros - digamos, lendo suas correspondências e recrutando informantes entre seus cortesãos de confiança - o sigilo tornou-se mais importante e, à medida que o sigilo era aumentado, a inteligência tornou-se mais vital. Destacando essa relação dinâmica, o comerciante e intelectual inglês Daniel Defoe argumentou perto da virada do século que,

$$
\begin{aligned}
& \text { “Como a inteligência no exterior é tão } \\
& \text { considerável, segue na proporção que a coisa mais } \\
& \text { útil em casa é o sigilo, pois, como a inteligência é } \\
& \text { a mais útil para nós, então manter nossos inimigos } \\
& \text { longes da inteligência é uma vantagem". (Defoe, } \\
& \text { 1704/1955, p. 264) }
\end{aligned}
$$

Esta característica complexa de governar através da raison d'Etat, portanto, moldou não apenas como os primeiros Estados modernos que procuraram desenvolver e proteger os conhecimentos que deles exigiam, mas também suas relações entre si e, portanto, a dinâmica do conjunto europeu.

\section{Reinventando a Inteligência II: Identificando Boas e Más Possibilidades}


$\mathrm{Na}$ segunda metade do século XVII, enquanto expor tramas, conspirações e projetos perigosos contra o Estado permaneceu importante, tornou-se assim cada vez mais vital aprender tanto quanto possível sobre os outros Estados; para descobrir "quais cartas estão nas mãos deles" para que alguém possa jogar a sua carta e possuir "a melhor vantagem". Com efeito, as diferentes ações refinadas por Thurloe procuraram não só movimentos e atividades de facções dissidentes e militares estrangeiros, mas também os pontos fortes e fraquezas, alianças e ambições dos aliados e adversários da Commonwealth - desenvolvendo um "conhecimento perfeito" de "tudo o que eles resolviam fazer" (Aubrey, 1990 , p. 101 $)^{47}$. Emissários ingleses enviados para o exterior foram instruídos a preservar relações pacíficas e monitorar tropas e desdobramentos navais, mas também para transmitir imediatamente ao Secretário quaisquer assuntos que possam ser de interesse para nós e nossos reinos", incluindo "as moções e intenções" do Tribunal, alterações na sua força disponível e em seu "tesouro", e quaisquer negociações ou propostas para o avanço do comércio. ${ }^{48}$

Mais discretamente, Thurloe também ordenou avaliações de caráter, forças e ambições de proeminentes nobres estrangeiros, ministros públicos e conselheiros reais, e até mesmo a "disposição dos comerciantes". ${ }^{49}$ Mais tarde, perto da virada do século, Daniel Defoe argumentou que, como este tipo de conhecimento será fundamental para muitas negociações do Secretário com seus vizinhos, ele deve ser inserido em uma "tabela" concisa e constantemente atualizado com

“(...) todos os ministros de Estado, listas de
famílias, conselhos privados e favoritos de todos

${ }^{47}$ Especialmente a França, a Espanha e os holandeses; veja Firth (1897b).

48 Extraído das instruções para Sir William Trumbull ao sair para a França; veja, Clark (1938, p. 104).

${ }^{49}$ Da confissão de Tomas Scot; impresso em Firth (1897, p. 122). 
os tribunais na Europa, e seus personagens, com listas exatas de suas forças, nomes de seus oficiais, estado de sua receita, métodos de governo, etc., tão justos e autênticos e atualizados regularmente conforme ocorrem alterações que através disso ele pode estimar devidamente a sua força, julgar seus interesses ... e tratar com eles de acordo ... cem mil libras por ano gastas ... em inteligências estrangeiras pode ser o melhor dinheiro que esta nação já colocou fora ... se algum dinheiro tivesse sido bem aplicado, nem a insurreição na Hungria nem a guerra na Polônia deveria ter sido tão fatal para a confederação como agora são". (Defoe, 1704/1955, p. 263)

É claro, monitorar monarquistas e republicanos no país e examinar as forças inimigas no campo permaneceram tarefas cruciais, e os esforços de Thurloe a esse respeito figuraram de forma proeminente nos tratamentos históricos do período (ver, por exemplo, Hobman, 1961; Aubrey, 1990). No entanto, enquanto isso levou alguns a afirmarem que a inteligência, portanto, "tem suas raízes nas forças armadas ...ou em requisitos de segurança e defesa" (Hibbert, 1990, p. 110), a inteligência também figurou proeminentemente nos esforços do Secretário para gerir os domínios ingleses no estrangeiro, estabilizar e melhorar as receitas do Estado, desenvolver e expandir o comércio inglês e coordenar relações diplomáticas.

Enquanto a volatilidade interna e a incerteza jurídica do Protetorado garantiram uma preocupação maior com a estabilidade doméstica, nem Thurloe nem Cromwell ignoravam outras formas de perigo, particularmente aqueles que podem ter impacto sobre a estabilidade financeira da Commonwealth e a força do comércio inglês. Enquanto caçavam cartas enviadas entre dissidentes conhecidos e não- 
conformistas, os deputados no escritório dos correios foram instruídos a copiar as "instruções", relatórios e outras formas de correspondência de e para os enviados diplomáticos em Londres. Espiões e informantes foram não só incumbidos de penetrar em facções e seitas indisciplinadas, ${ }^{50}$ mas também com a observação das idas e vindas de estrangeiros embaixadores, enviados diplomáticos e comerciantes proeminentes, sempre que possível, descobrindo a natureza de suas reuniões e secretamente capturando seus pacotes.

Para este fim, Thurloe recrutou espiões não só em Londres e na França (onde viveu o príncipe exilado e sua corte), mas "no exterior quase em cada condado e cidade, ou centro urbano". ${ }^{51}$ A integração deste material tão diverso - digamos, um relatório transmitindo a nomeação de um novo Secretário da Marinha na França, relatos dos mais frequentes encontros dos enviados franceses à Corte espanhola, e um relato de conferências privadas entre o embaixador espanhol em Paris e os Secretários Franceses de Estado - revelou a possibilidade não de guerra, mas de iminente acordo comercial entre a França e a Espanha; um prospecto que teria implicações particulares para a voracidade do comércio inglês e sua continua estabilidade financeira.

Isto é, para a raison d'Etat de meados do século, não é apenas a preservação do Estado que deve ser assegurada, mas também - e cada vez mais - o seu desenvolvimento, expansão e crescimento. Enquanto a Inglaterra não enviava uma delegação a Osnabruck ou a Munster, ela foi, no entanto, obrigada a formar cada vez mais uma rivalidade econômica e comercial que caracterizava as relações entre Estados europeus - um desenvolvimento tanto hábil e acelerado pelos tratados em 1648. Como a

50 Tanto aqueles em casa como no exterior, como o "Nó Selado", um grupo de nobres exilados na França que procuravam coordenar levantes monarquistas na Inglaterra (Aubrey, 1990, p. 95-96).

${ }^{51}$ Do breve discurso de Wildman sobre o negócio da inteligência (ver, Firth, 1898, p. 532). 
preservação do Estado foi rearticulada como uma questão de assegurar paz e estabilidade enquanto renovava as forças, o conhecimento exigido pela raison d'Etat também mudou conforme o imperativo de proteção era cada vez mais complementado pela necessidade de adquirir e manter domínio econômico e comercial. Isto obrigou não só a descobrir e prevenir riscos para a estabilidade, mas também a identificação e exploração de oportunidades potenciais de vantagem ou ganho. Em outras palavras, a preocupação bem ensaiada do Protetorado com a estabilidade interna era aliada a um requerimento obrigatório e um pouco menos pronunciado de garantir e expandir o comércio inglês, para aumentar o domínio colonial e o controle sobre os mares, e para melhorar a posição da Commonwealth em relação aos seus vizinhos. Em termos práticos, isso significava que os relatórios de guerra iminente entre a Suécia e os Estados do Norte, ou relatos de tratado iminente entre a França e a Espanha precisariam ser entendidas e avaliadas não apenas em termos de problemas que eles poderiam gerar sob a paz e a estabilidade, mas também em termos das oportunidades que poderiam estar presentes para expansão e crescimento.

A dissolução de relacionamentos duradouros, por exemplo, pode sinalizar novas oportunidades para chegar a um acordo com Estados anteriormente engajados, enquanto futuras alianças tornaram-se possíveis (mesmo necessárias) para a consideração de novas parcerias. Depois da Restauração, tais "considerações de comércio" só se aprofundariam e se intensificariam com a força financeira Inglesa tornando-se uma prioridade para Carlos II (ver Firth, 1897b, p. 319).

\subsection{Inteligência como uma forma de "estimativa"}

Como tudo isso sugere, o modelo de inteligência de Thurloe compreendia vários mecanismos diferentes para gerar informação; informações necessárias tanto para evitar o perigo quanto para identificar oportunidades, mas que muitas vezes era difícil de ser encontrada. Alguns 
dos procedimentos por ele refinados não eram em si mesmos novos usando espiões, trocando cartas com enviados diplomáticos e até mesmo interceptando correspondência suspeita, são encontrados muito antes do século XVII (ver, por exemplo, Elias, 1983; Plowden, 1991; Hayes, 1992; Breight, 1996). E ainda assim, enquanto Thurloe certamente reinventou e estendeu essas medidas em um ambiente bastante inovador, grande parte da novidade em sua abordagem não está nas práticas individuais em si, mas em sua integração, sistematização e (re)direção por intermédio do escritório da Secretaria de Estado e a rearticulação de todo o aparato nos interesses do Estado.

De fato, a visão de inteligência de Thurloe foi notavelmente voltada para o futuro, visualizando tanto os problemas para a paz e para a estabilidade, bem como oportunidades de vantagem e ganho; como sempre, apenas as possibilidades que poderiam (portanto) ser previstas e manipuladas para o melhor efeito. Como Foucault (2007) deixou claro, vendo acontecimentos desta maneira - como "eventualidades" remotas e ainda indeterminadas - é decididamente um esforço governamental. Ao contrário da soberania, a arte do governo é orientada para o futuro e envolve a "correta disposição das coisas" para levar a "fins adequados"; fins que são sempre mais do que o sua própria continuação (Foucault, 2007, p. 98; com base em La Perriere, 1598). ${ }^{52}$ Desde que os fins do governo estão sempre "distantes" no espaço e no tempo, os obstáculos para alcançar esses fins sempre aparecerão como "possibilidades" que podem ser conhecidas, calculadas e governadas. Tomando emprestada a analogia de Foucault (2007, p. 97), governar um navio significa, portanto, cuidar de seus marinheiros, sua embarcação e sua carga, mas também significa atender às "possíveis eventualidades" como ventos fortes, recifes

52 A soberania também tem um "fim", mas que é caracterizado em termos do "bem comum" - uma condição na qual os sujeitos obedecem à lei e respeitam a ordem estabelecida. Assim, "o fim da soberania é circular; refere-se novamente ao exercício da soberania" (Foucault, 2007, p. 98). 
perigosos e potenciais tempestades; significa "levar em consideração possíveis eventos ...".

Dito de outra forma, a arte da inteligência de Thurloe só era possível se os eventos, desenvolvimentos e processos vitais para a preservação e expansão do Estado fossem concebidos como potencialidades que podem ser previstas e gerenciadas. Esta abordagem da inteligência é, portanto, distintamente governamental, procurando produzir o conhecimento necessário para cálculos sobre o futuro. $\mathrm{E}$ ainda, dada as preocupações inequivocamente orientadas para o futuro da raison d'Etat de meados do século - para evitar riscos para o Estado enquanto aproveita oportunidades de crescimento - e rotinas onipresentes de sigilo, algo mais é exigido de inteligência, algo diferente. $\mathrm{Na}$ verdade, a arte da visão de Thurloe para a inteligência não era baseada apenas na leitura de cartas privadas, roubo de segredos e acúmulo de informações, mas combinando, comparando e ordenando formas bastante diferentes de informação de maneira que de outra forma não eram visíveis. Seu aparato englobava mais do que apenas um conjunto de dispositivos de coleta de informações; ter uma "visão constante das coisas" era apenas uma dimensão para a inteligência, e uma visão que adquiriu sua utilidade e importância em termos de um conjunto muito mais amplo de procedimentos.

Para tornar todas essas informações úteis, um conjunto de processos também precisava ser desenvolvido para organizar, compilar, contrastar e sintetizar os inúmeros relatórios, narrações e cartas que o escritório recebia de toda a Europa. Testemunhos escritos de eventos nas principais cidades europeias, relatórios sobre as deliberações de alguns tribunais distantes, contas internas de negociações em curso, relatórios de recentes movimentos de tropas, e assim por diante, todos tiveram que ser lidos e compilados, contrastados e comparados, e integrados com o que já era conhecido. As cartas criptografadas e muitas vezes anônimas transmitidas por espiões tinham que ser autenticadas e decifradas, fundamentadas e corroboradas, antes que pudessem ser fundidas com 
outras contas. A correspondência duplicada, juntamente com as anotações pessoais dos abridores de cartas, teve que ser examinada, peneirada e colecionada em detalhes. E todo esse material bem distinto tinha que ser montado e organizado, avaliado e pensado de maneira que o tornassem tanto manejável quanto útil.

Grande parte desse trabalho organizacional recaiu sobre os muitos deputados, secretários e assistentes do Secretário (e eventualmente um número de subsecretários) que acumulou, arranjou e até priorizou muito do que Thurloe acabaria por ver. Através desses procedimentos, um fluxo razoavelmente contínuo de informações bastante variáveis - em diferentes formatos e de diferentes fontes, regiões e horários - poderia ser reunido em um corpo de conhecimento coerente, embora em constante desenvolvimento, constantemente atualizado e refinado, falado e dissecado, de maneira que revelavam coisas que não imediatamente eram discerníveis de um único relatório ou carta. Na evidência explícita de algum perigo iminente - iminente no sentido: "problemas iminentes de dentro [ou] invasões do exterior" ${ }^{53}$ - eram imediatamente passados para Thurloe (e, através dele, para Cromwell), mas a rotinização de processos sistemáticos para ler, classificar, integrar e agrupar informações permitiu algo mais. Ao invés de ficar esperando que uma carta oportuna e condenatória fosse apreendida nos correios ou um espião de confiança descobrisse as sementes da insurreição, as dimensões organizacionais da inteligência permitiram que informações circunstanciadas ou indiretas fossem combinadas e justapostas de maneira que expusessem alguma possibilidade (desagradável ou vantajosa), incluindo suas dimensões e sua severidade potencial.

Embora tais processos possam parecer bastante brutos quando comparados às práticas atuais, eles foram bastante inovadores para a

53 A partir do relato de Thomas Scot sobre suas ações como um intérprete durante a Commonwealth (impresso em Firth, 1897, p. 125). 
época. A integração de diversas formas de material permitiu que novas informações adquirissem seus sentidos e significados não apenas em termos do que implicou diretamente, mas também em termos do que revelou quando foi combinado com outras informações, e com o que já era conhecido. Relatórios de um surto de cartas enviadas através de transportadoras privadas em Londres, o aumento da atividade em torno da residência do embaixador francês, relatos dos condados sobre o número crescente de assembleias noturnas e relatórios de espiões na França sobre as reuniões mais frequentes do "Nó Selado"54 - quando tomadas em conjunto - indicaram algo particular sobre a perspectiva de uma revolta geral, e até permitiu a estimativa de sua probabilidade, severidade e impacto. Avisos do continente sobre a degradação das relações entre os Estados do Norte, relatórios de implantação de tropas ao longo das fronteiras e de comerciantes que fogem de grandes portos, sugeriu não só a guerra iminente, mas também novas oportunidades por propor negociações comerciais com vizinhos que em breve entrariam em guerra.

Manipulando informações de tal maneira, a arte da inteligência incorporou o que poderia ser referido como uma forma inicial de "estimativa" ${ }^{5}$ - um meio não probabilístico para identificar boas e más possibilidades para o Estado. Técnicas de estimativa implementaram assembleias de instrumentos que coletivamente buscaram tornar possíveis (incertos) cálculos sobre o futuro. O'Malley \& Roberts caracterizam um desses agenciamentos como "perigosidade cumulativa"; uma forma de estimativa que aparece na prática inicial de seguro, e que usa a epistemologia da lista e do olhar inspecional para acumular mais e mais informações para chegar em direção ao conhecimento perfeito.

Em termos governamentais, tais técnicas fornecem as précondições necessárias de intervenção (governamental) concreta,

54 NT O "Nó Selado" foi uma associação secreta que lutava pela restauração da Monarquia na Inglaterra.

${ }^{55}$ Sou grato a Pat O'Malley por apontar isso. 
permitindo que o conhecimento seja desenvolvido, delineado e diagnosticado de maneira particular (ver também Rose \& Miller, 1992; Walters, 2002). Como todas as formas de razão governamental, a arte de governar através da raison d'Etat "depende de cálculos feitos em um lugar sobre como afetar as coisas em outro" (Rose \& Miller, 1992, p. 238), e é, portanto, totalmente contingente com certas formas de cálculo. Diferentes formas de cálculo, por sua vez, requerem um conhecimento específico sobre o futuro; conhecimento que deve ser produzido e montado em "locales" (ou "centros de cálculo") onde podem ser trabalhados, ordenados e tornados úteis para o governo.

A arte da inteligência de Thurloe, portanto, compreendia um conjunto de "dispositivos de inscrição" - as cartas, relatórios e narrações solicitados pelo seu escritório - que transformaram eventos distantes e processos em "informações" que poderiam ser transmitidas a Londres (ver Latour, 1987; ver também, Rose e Miller, 1992; Walters, 2002). Mas também envolveu um conjunto de procedimentos para integrar, comparar e justapor este material de forma a tornar possíveis futuros visíveis, pensáveis e governáveis. Neste sentido, a inteligência tornou o governo através da raison d'Etat ao mesmo tempo possível e eficaz. Em outras palavras, os perigos e oportunidades que o Estado precisava administrar primeiro foram projetados de forma governável; isto é, eles tiveram que ser representados e descritos de uma maneira que permitiria que eles fossem pensados, discutidos e postos em prática. Este processo de "compor" ou constituir possíveis riscos/oportunidades é inerentemente governamental: ele não busca "reproduzir o visível", mas sim "tornar visível" para fins de governo (Miller, 1990, p. 317). ${ }^{56}$ Em um sentido

56 A estatística, por exemplo, é o conhecimento do Estado, mas é também um meio de constituir o Estado como uma entidade visível, mensurável e manipulável (ver, por exemplo, Hacking, 1990). Isto é, medindo e atribuindo valores e categorias a aspectos específicos do Estado, "o Estado" é literalmente construído de forma concreta. Da mesma forma, a contabilidade é mais do que apenas um mecanismo técnico para registrar 
bastante literal, a arte da inteligência de Thurloe construiu possíveis eventos futuros como "objetos-problema" concretos, pensáveis e governáveis (Walters, 2002, p. 91).

\section{Discussão: Inteligência como técnica governamental}

Como tudo isto deixa claro, as realidades de um campo europeu de concorrência e de troca entre Estados e os requisitos da raison d'Etat de meados do século - incluindo a necessidade de desenvolver conhecimento em um ambiente saturado por rotinas de sigilo - forneceram as condições necessárias para a invenção de uma nova técnica governamental que permitia cálculos sobre o futuro. Produzir e manipular informações (frequentemente secretas) de maneira que revelassem possíveis riscos e oportunidades para o Estado, a inteligência compreendida em um conjunto de práticas não era para "dominar o Estado" (Miller \& Rose, 1990), mas sim para compilar tudo o que poderia afetar sua estabilidade e crescimento. Isso certamente incluía quaisquer ameaças iminentes internas ou externas. No entanto, elas deveriam ser visualizadas e representadas como meramente uma forma (vantajosa ou desagradável) de possibilidade. $\mathrm{Na}$ busca da força contínua, estabilidade e expansão do Commonwealth, a arte da inteligência de Thurloe, portanto, contribuiu para a formação e crescimento do Estado moderno.

Seus esforços para estabelecer um sistema universal de correspondência - como um mecanismo para controlar os fluxos de informação - e o desenvolvimento de um correio administrado pelo Estado pós-constituição da Commonwealth com instituições específicas, os aparelhos e transmissões perduraram por algum tempo como as principais dimensões do Estado inglês. Ao fornecer-lhe vantagem estratégica em suas

transações econômicas; Como Peter Miller (1990) mostrou, ao atribuir valores financeiros a práticas sociais específicas, os procedimentos contábeis inscrevem certos processos com uma visibilidade concreta, calculabilidade e "utilidade operacional". 
relações e negociações com seus vizinhos europeus, e ao limitar a capacidade de seus rivais de dominar o comércio, controlar os mares e dominar as colônias, a inteligência também funcionava como uma característica constitutiva da estabilidade e do equilíbrio europeus. Isso fornece um corretivo útil para a percepção não incomum de que a inteligência era (e é) inerentemente sobre descobrir e prevenir ameaças. Se a arte da inteligência está realmente ligada a raison d'Etat de meados do século, como foi mostrado aqui, então a noção de que suas raízes podem ser encontradas em requerimentos militares e de defesa também podem ser questionados. De fato, a necessidade de desenvolver conhecimento comercialmente relevante não é apenas evidente no formato de Thurloe, ela também se intensifica após a Restauração em 1660, quando as prioridades inglesas mudaram ainda mais para o comércio, a expansão colonial e a solidez financeira.

Talvez mais crucialmente, esta análise revela uma maneira inteiramente nova de pensar e estudar a inteligência. Como uma forma de técnica governamental que aparece bem cedo na genealogia do Estado poder/conhecimento, inteligência deve assumir uma posição mais proeminente nas análises foucaultianas que tradicionalmente evitam sua forma, trajetória e mutações. Uma das contribuições de Foucault mais importantes foi a ideia de que as técnicas têm suas próprias histórias que podem ser consideradas independentemente de qualquer lógica ou racionalidade específica. Portanto,

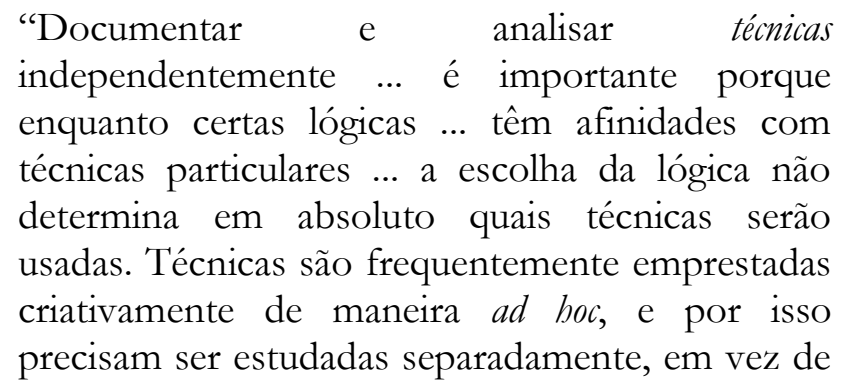


ser relegadas ao domínio extra-teórico da "implementação". (Valverde, 2011, p. 9; ênfase no original)"

Em outras palavras, não há nada que inerentemente ligue a inteligência à raison d'Etat e um caminho útil a seguir seria continuar diagnosticando suas muitas variações históricas e contemporâneas. Já houve um trabalho realizado sobre "inteligência nacional" e (cada vez mais) sobre "policiamento liderado por inteligência", mas muito mais precisa ser feito. $\mathrm{Na}$ verdade, nosso presente parece quase saturado com diferentes modelos de inteligência, tanto dentro quanto fora do Estado, o que parece estar desempenhando um papel cada vez mais central em governar campos tão diversos quanto a prevenção a incêndios, saúde e doenças, negócios, fronteiras e criminalidade. Adicionando estudos de inteligência ao crescente corpo de trabalho sobre lógicas e técnicas contemporâneas antecipatórias seria, portanto, de grande valor. Uma bem temperada e hoje bastante comum técnica, a inteligência merece um lugar ao lado do risco probabilístico, da preparação, da resiliência e da precaução. $^{57}$

\section{Referências}

Aclin, J. (2010). Intelligence as a Tool of Strategy. In Bartholomees, J. B. (Ed.) The US Army War College Guide to National Security Issues, Volume I: Theory of War and Strategy. Carlisle, PA: US Army War College. Pp. 263-277.

Andrew, C. \& Noakes, J. (1987). (Eds.). Intelligence and International Relations, 1900-1945. Exeter: University of Exeter Press.

${ }^{57}$ Veja, por exemplo, O'Malley (2004), Lakoff (2006), Lentzos \& Rose (2009), O'Malley (2010). 
Andrew, C. (1985). Secret Service: The Making of the British Intelligence Community. London: William Heinemann.

Aubrey, P. (1990). Mr Secretary Thurloe: Cromwell's Secretary of State, 1652-1660. London: The Athlone Press.

Bacon, Sir F. (1625/1985). The essayes or counsels, civill and morall. Edited and introduced by Michael Kiernan. Oxford: Clarendon Press.

Ball, P. (2004). Critical Mass: How One Thing Leads to Another. New York: Farrar, Straus \& Giroux.Barry, A., Osborne, T., \& Rose, N. (1996). (Eds.). Foucault and Political Reason: Liberalism, Neo-Liberalism and Rationalities of Government. Abingdon, Oxon: Routledge.

Birch, T. (1849). The Court and Times of James the First. London: Henry Colburn, Publisher.

Bond, F. W. (1955). Samuel Moreland and the Secret Opening of Letters. Postal History Society Bulletin, 79, 26-28.

Botero, G. (1606). The Reason of State (and The Greatness of Cities). Translated by P.J. and D.P. Waley, with an introduction by D.P. Waley. London: Routledge \& Keegan Paul.

Breight, C. (1996). Surveillance, Militarism, and Drama in Elizabethan England. London: Macmillan Press.

Brian, E. (1994). La Mesure de l'Etat: Administrateurs et géomètres au XVIIIe siècle. Paris: Albin-Michel.

Brown, A. L. (1968). The King's Councillors in Fifteenth Century England. Transactions of the Royal Historical Society, 5th Series, v. 19.

Burchell, G., Gordon, C. \& Miller, P. (1991). (Eds.). The Foucault Effect: Studies in Governmentality. London: Harvester Wheatsheaf.

Cain, F. (1994). The Australian Security Intelligence Organisation: An Unofficial History. Newbury Park: Frank Cass.

Clark, R. (1938). Sir William Trumbull in Paris, 1685-1686. Cambridge: Cambridge University Press.

Clarke, B. (2004). From Grub Street to Fleet Street: An Illustrated History of English Newspapers to 1899. Aldershot: Ashgate. 


\section{DELICTAE, Vol. 4, No6, Jan..-Jun. $2019 \mid 155$}

Codevilla, A. (1992). Informing Statecraft: Intelligence for a New Century. New York: Free Press.

Couvee, C. (1956). Book Review: The Intelligence of the Secretaries of State and their Monopoly of Licensed News, 1660-1688. By P. Fraser (1956). International Communication Gazette, 2: 250.

Darling, A. B. (1990). The Central Intelligence Agency: An Instrument of Government to 1950. University Park: Pennsylvania University Press.

Deacon, R. (1970). A History of the British Secret Service. New York: Taplinger.

Defoe, D. (1704/1955). The Letters of Daniel Defoe. Edited by George Harris Healy. Oxford: Clarendon Press.

Der Derian, J. (1992). Antidiplomacy: Spies, Speed, Terror and War. London: Basil Blackwell Press.

Deutsch, H. C. (1977). The Historical Impact of Revealing the ULTRA Secret. Parameters, 7/3, 16-32.

Dicey, A. V. (1760). The Privy Council. Oxford: T. \& G. Shrimpton.

Dillon, M. (2003). Intelligence Incarnate: Martial Corporeality in the Digital Age. Body and Society, 9, 123-146.

Elias, N. (1983). The Court Society (Translated by Edmund Jephcott). Oxford: Blackwell.

Elton, G. R. (1962). The Tudor Revolution in Government: Administrative Changes in the Reign of Henry the VIII. Cambridge: Cambridge University Press.

Evans, F. (1923). The Principal Secretary of State: A Survey of the Office From 1558 to 1680. Manchester: University of Manchester Press.

Farago, L. (1962). Burn After Reading: The Espionage History of World War II. New York: Walker.

Fergusson, T. G. (1984). British Military Intelligence, 1870-1914: The Development of a Modern Intelligence Organisation. Frederick: University Publications of America.

Ferris, J. (1989). Before 'Room 40': The British Empire and Signals Intelligence, 1898-1914. Journal of Strategic Studies, 12, 431-457. 
Firth, C. H. (1897). Thomas Scott's Account of His Actions as Intelligencer during the Commonwealth. The English Historical Review, 12, 116-126.

Firth, C. H. (1897b). Secretary Thurloe on the Relations of England and Holland. English Historical Review, 21/82, 319-327.

Firth, C. H. (1898). Thurloe and the Post Office. The English Historical Review, 13, 527-533.

Foucault, M. (1988/1981). Politics, Philosophy and Culture: Interviews and Other Writings, 1977-1984. Translated by A. Sheridan, Edited by L. D. Kritzman. London: Routledge.

Foucault, M. (1991). Governmentality. In G. Burchell, C. Gordon \& P. Miller (Eds.) The Foucault Effect: Studies in Governmentality. London: Harvester Wheatsheaf.

Foucault, M. (2007). Security, Territory, Population: Lectures at the College de France, 1977-1978. Edited by Michel Senellart; General Editors Francois Ewald and Alessandro Fontana. Translated by Graeme Burchell. Palgrave/Macmillan.

Fraser, P. (1956). The Intelligence of the Secretaries of State. Cambridge: Cambridge University Press.

Gill, P. (2000). Rounding Up the Usual Suspects? Developments in Contemporary Law Enforcement Intelligence. Aldershot: Ashgate.

Gill, P. (2006). Not Just Joining the Dots But Crossing the Borders and Bridging the Voids: Constructing Security Networks After 11 September 2001. Policing and Society, 16 (1), 27-49.

Gunn, S. J. (1995). Early Tudor Government, 1485-1558. New York: St. Martin's Press.

Hacking, I. (1982). Biopower and the Avalanche of Printed Numbers. Humanities in Society, 5, 279-285.

Hacking, I. (1990). The Taming of Chance. Cambridge: Cambridge University Press.

Hald, A. (2003). A History of Probability and Statistics and Their Applications Before 1750. New Jersey: Wiley. 
Hastedt, G. P. (1991). Intelligence and US Foreign Policy: How to Measure Success? International Journal of Intelligence and Counterintelligence, 5, 49-62.

Hayes, A. (1992). Invisible Power: The Elizabethan Secret Services, 15701603. New York: St. Martin's Press.

Helt, J.S.W. (1994). Review: Invisible Power: The Elizabethan Secret Services, 1570-1603. Sixteenth Century Journal, 25, 494-495.

Hibbert, R. (1990). Intelligence and Policy. Intelligence and National Security, 5/1, 110-128.

Higham, F. (1925). A Note on the Pre-Tudor Secretary. In A.G. Little \& F.M. Powicke (Eds.). Essays in Medieval History Presented to T.F. Tout. Manchester: Printed for the Subscribers.

Hobman, D.L. (1961). Cromwell's Master Spy: A Study of John Thurloe. London: Chapman \& Hall.

Hyde, J. W. (1894). The Early History of the Post in Grant and Farm. London: Adam and Charles Black.

Johnson, S. (1773). A Dictionary of the English Language (in which the words are deduced from their originals, and illustrated in their different significations by examples from the best writers). 4th Edition. London: Strahan \& Rivington.

Joyce, H. (1893). History of the Post Office From its Establishment Down to 1836.

Jusserand, J. J. (1892). A French Ambassador at the Court of Charles the Second: The Comte de Cominges, From His Unpublished Correspondence. New York: G.P. Putnam's Sons.

Kahn, D. (1985). Codebreaking in World Wars I and II: The Major Successes and Failures, Their Causes and Their Effects. In Andrew, C. \& Dilks, D. (Eds.) The Missing Dimension: Governments and Intelligence Communities in the Twentieth Century. Urbana: University of Illinois Press. Pp. 138-158.

Karalekas, A. (1977). History of the Central Intelligence Agency. Laguna Hills: Aegean Park Press. 


\section{DELICTAE, Vol. 4, No6, Jan..-Jun. $2019 \mid 158$}

Kent, S. (1949). Strategic Intelligence for American World Policy. Princeton University Press.

Kleimola, A. M. (1987). Ivan the Terrible and his 'Go-Fers': Aspects of State Security in the 1560's. Russian History, 19, 283-292.

Lakoff, A. (2006). Techniques of Preparedness. In T. Monahan (Ed.). Surveillance and Security: Technological Politics and Power in Everyday Life. New York: Routledge.

La Perriere, de G. (1598). The Mirrovr of Policie. British Library.

Latour, B. (1986). The Powers of Association. In J. Law (Ed.). Power, Action and Belief. London: Routledge.

Lentzos, F. \& Rose, N. (2009). Governing Insecurity: Contingency Planning, Protection, Resistence. Economy \& Society, 38, 230-254.

Levy, L. M. (1985). The Emergence of a Free Press. Oxford: Oxford University Press.

Marshall, A. (1994). Intelligence and Espionage in the Reign of Charles II: 1660-1685. Cambridge: Cambridge University Press.

Marshall, A. (2003). Sir Samuel Moreland and Stuart Espionage. A King Charles Lecture, Bath Spa University College.

Miller, P. \& Rose, N. (1990). Governing Economic Life. Economy and Society, 19, 1-31.

Miller, P. (1986). Accounting for Progress - National Accounting and Planning in France: A Review Essay. Accounting, Organisations and Society, 83-104.

Miller, P. (1990). On the Interrelations Between Accounting and the State. Accounting, Organisations and Society, 15, 315-338.

Muddiman, J. G. (1923). The Kings Journalist, 1659-1689: Studies in the Reign of Charles II. London: Lane Bodley Head.

Neocleous, M. (2003). Imagining the State. Maidenhead: Open University Press.

O'Malley, P. (2004). Risk, Uncertainty and Government. London: Glasshouse Press. 
O'Malley, P. (2010). Resilient Subjects: Uncertainty, Warfare and Liberalism. Economy and Society, 39, 488-509.

O'Malley, P. \& Roberts, A. (Forthcoming, 2014). 'Governmental Conditions for the Economisation of Uncertainty: Fire Insurance, Regulation and Insurance Actuarialism.' Journal of Cultural Economy.

Palazzo, G. A. (1611). Discours du gouvernement et de la raison vraye d'Estat. Translated by Adrien de Vallières. Douai: De Bellire,

Plowden, A. (1991). The Elizabethan Secret Service. Hertfordshire: Harvester Wheatsheaf.

Porter, T. (1986). The Rise of Statistical Thinking, 1820-1900. Princeton: Princeton University Press.

Rathmell, A. (2002). Towards Postmodern Intelligence. Intelligence and National Security, 17/3, 87-104.

Rose, N. \& Miller, P. (1992). Political Power Beyond the State: Problematics of Government. British Journal of Sociology, 43, 172-205.

Sabin, M. (1985). The Community of Intelligence and the Avant-Garde. Raritan, 4(3), 1-25.

Seth, R. (1957). The Art of Spying. New York: Philosophical Library.

Stephens, M. (2007). A History of News. Oxford: Oxford University Press.

Stigler, S. M. (1986). The History of Statistics: The Measurement of Uncertainty Before 1900. Boston: Harvard University Press.

Thuau, E. (1966). Raison d'Etat et Pensee Politique a l'Epoque de Richelieu. Paris: Collins.

Trevor-Roper, H. (1959). The General Crisis of the Seventeenth Century. Past \& Present, 16.

Turner, E. R. (1918). The Secrecy of the Post. English Historical Review, 33, 320-327.

Walters, W. (2002). The Power of Inscription: Beyond Social Construction and Deconstruction in European Integration Studies. Millennium Journal of International Studies, 31, 83-108. 
Whyman, S. (2000). Postal Censorship in England, 1635-1844. Postcomm. Retrived August, 2013.

Williams, J.B. (1908) (Pseudonym J. G. Muddiman). A History of English Journalism to the Foundations of the Gazette. London: Longman's.

Valverde, M. (2007). Genealogies of European States: Foucauldian Reflections. Economy and Society, 36/1, 159-178.

Valverde, M. (2011). Questions of Security: A Framework for Research. Theoretical Criminology, 15, 3-22. 